\title{
HMGN3 wt Allele
}

National Cancer Institute

\section{Source}

National Cancer Institute. HMGN3 wt Allele. NCI Thesaurus. Code C52081.

Human HMGN3 wild-type allele is located in the vicinity of $6 q 14.1$ and is approximately 33 $\mathrm{kb}$ in length. This allele, which encodes high mobility group nucleosome-binding domaincontaining protein 3 , plays a role in both thyroid receptor beta binding and modulation of chromatin modifications. 